\title{
Ring chromosome 13
}

\section{Francisco Cammarata-Scalisi ${ }^{*}$, Yajaira Briceño ${ }^{2}$, Edymar Cegarra $^{3}$ and Daniela Montilla ${ }^{4}$}

${ }^{1}$ Unidad de Genética Médica, Departamento de Puericultura y Pediatría, Facultad de Medicina, Universidad de Los Andes; ${ }^{2}$ Unidad́ de

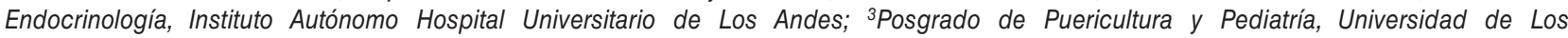
Andes; ${ }^{4}$ Departamento de Microbiología y Parasitología, Cátedra de Inmunología, Facultad de Farmacia y Bioanálisis, Universidad de Los Andes. Mérida, Venezuela

\begin{abstract}
Background: Ring chromosome 13 is an infrequent cytogenetic disorder clinically characterized by growth and psychomotor development retardation, cognitive deficit, microcephaly, facial dysmorphism, genital alterations and thumb hypoplasia. Case report: A 8-month-old patient was evaluated for presenting short stature, psychomotor development delay, microcephaly, facial dysmorphism, penoscrotal hypospadias and thumb hypoplasia. Lissencephaly, neuroconductive hearing loss oñ the right side and small ostium secundum interatrial communication were evident. The cytogenetic study of the patient showed $46, X Y, r(13)$ in 30 cells analyzed. Conclusions: Clinical findings that can guide the diagnosis of this infrequent structural chromosomal alteration are highlighted, as well as the interdisciplinary medical evaluation required and adequate family
\end{abstract} genetic counseling.

Key words: Ring chromosome 13. 46, XY, r (13). Clinic. Genetic counseling.

\section{Cromosoma 13 en anillo}

\section{Resumen}

Introducción: El cromosoma 13 en anillo es una alteración citogenética infrecuente, clínicamente caracterizada por presentar retraso del crecimiento, del desarrollo psicomotor y déficit cognitivo, además de microcefalia, dismorfia facial, alteraciones genitales e hipoplasia del pulgar. Caso clínico: Paciente de 8 meses de edad evaluado por presentar talla baja, retraso del desarrollo psicomotor, microcefalia, dismorfia facial, hipospadias peneoescrotales e hipoplasia de pulgar. Se evidẹció lisencefalia, hipoacusia neuroconductiva del lado derecho y comunicación interauricular tipo ostium secundum pequeña. El estudio citogenético del paciente mostró 46, XY, r (13) en 30 células analizadas. Conclusiones: Se resaltan los hallazgos clínicos que pueden orientar el diagnóstico de esta alteración cromosómica estructural infrecuente, destacando ademâs, la evaluación médica interdisciplinaria requerida y el adecuado asesoramiento genético familiar.

Palabras clave: Cromosoma 13 en anillo. 46, XY, r (13). Clínica. Asesoramiento genético.

Available online: 14-01-2020 Bol Med Hosp Infant Mex. 2019; 76:93-96 www.bmhim.com 


\section{Introduction}

A ring chromosome occurs after a rupture in both arms of a chromosome, followed by the fusion of the broken ends to complete the ring. ${ }^{1-3}$ Although infrequent, this type of cytogenetic alteration has been described in each human chromosome. ${ }^{4}$ The clinical characteristics observed in this alteration vary depending on the number and function of the genes that present deletion, duplication, and stability of the ring. ${ }^{1}$

Ring chromosome 13 is an infrequent cytogenetic alteration first described in 1968 by Lejeune et al. ${ }^{2,5}$ It has an estimated incidence of 1 in 58,000 live births ${ }^{1,5,6}$ and is more common in females $(60 \%) .{ }^{6}$ Most of the cases reported in the literature are de novo, ${ }^{1,2}$ although hereditary cases have been reported as well. ${ }^{1,4}$ Clinical characteristics include intrauterine growth retardation, neural tube closure defect, alterations in the central nervous system, ${ }^{5}$ seizures, ${ }^{3}$ psychomotor development delay, ${ }^{2}$ moderate to severe cognitive deficit, growth deficiency, microcephaly, ${ }^{1-3,5,6}$ ocular alterations, hipoacusia $^{3}$ facial dysmorphism characterized by high anterior hairline, hypertelorism, down slanted palpebral fissures, broad nasal bridge, thin lips and microstomia, in addition to congenital heart disease,,$^{3,6}$ genital alterations in males that include cryptorchidism and hypospadias, ${ }^{1,2,5}$ anal atresia, ${ }^{3}$ and thumb hypoplasia ${ }^{1}$ (Table 1). These characteristics are similar or more serious $^{2,5,7}$ than those observed in the carriers of the long arm deletion of chromosome 13.

The clinical severity found in cases of ring chromosome 13 is broad. ${ }^{3,6}$ The loss of genes from $13 q 34$ can contribute to the phenotype. ${ }^{5}$ However, the genotype-phenotype correlation has not been identified. ${ }^{2}$

The present work aims to report a case of ring chromosome 13 and the different clinical findings that can guide its diagnosis, as well as highlighting the importance of providing an interdisciplinary medical evaluation and adequate genetic counseling.

\section{Clinical case}

A male patient of 8 months of age was evaluated for presenting psychomotor development delay, short stature, microcephaly, facial dysmorphia, and penoscrotal hypospadias.

At the time of conception, the father was 23 , and the mother was 19 years old, both healthy and non-consanguineous. The patient is the product of the first pregnancy of the mother, who was treated for urinary tract infection in the sixth month. The patient had a prenatal
Table 1. Clinical findings of ring chromosome 13 syndrome

\begin{tabular}{|l|l} 
Findings in literature ${ }^{1-3,5,6}$ & $\begin{array}{c}\text { Findings in the patient } \\
\text { (12 months of age) }\end{array}$
\end{tabular}

\begin{tabular}{|c|c|c|}
\hline Neural tube closure defect & - & है \\
\hline Intrauterine growth delay & + & (2) \\
\hline Low height & + & \\
\hline Nervous system alterations & + & $\frac{n}{n}$ \\
\hline Microcephaly & + & $\frac{0}{2}$ \\
\hline High anterior hairline & + & a \\
\hline Frontal prominence & + & + \\
\hline Eye disorders & - & 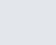 \\
\hline Hypertelorism & - & $\underline{\widetilde{n}}$ \\
\hline Down slanted palpebral fissure & - & $\frac{5}{9}$ \\
\hline Wide and depressed nasal bridge & + & $\subset$ \\
\hline Thin lips & - & \pm \\
\hline Microstomia & + & 3 \\
\hline Prominent incisors & NS & $\cdot \frac{0}{2}$ \\
\hline Hearing loss & + & 0 \\
\hline Prominent auricular pavilions & - & + \\
\hline Hypothyroidism & - & 온 \\
\hline Congenital heart disease & + & 3 \\
\hline Renal alterations & + & $\cong$ \\
\hline Ambiguous genitalia & - & 응 \\
\hline Hypospadias & + & 웅 \\
\hline Cryptorchidism & - & 응 \\
\hline Anal atresia & - & $\overline{0}$ \\
\hline Thumb hypoplasia & + & y \\
\hline Cognitive deficit & NS & ర \\
\hline Delay in language & + & 인 \\
\hline Autism & NS & ـ \\
\hline Seizures & - & $\vec{c}$ \\
\hline Retinoblastoma & - & ᄃิ \\
\hline Decreased survival & NS & ד \\
\hline sent; -, absent; NS, not specified (findir & & o \\
\hline
\end{tabular}

diagnosis of intrauterine growth retardation. The patient was born by cesarean section at 35 weeks of gestation, without complications, with a birth weight of $2,200 \mathrm{~g}$ (standard deviation [SD]: -2.7) and a size of $45^{\circ} \mathrm{cm}$ (SD: -4.1). 
At 12 months of age, the patient was $67 \mathrm{~cm}$ (SD: -3.6) of size, $6.9 \mathrm{~kg}$ (SD -3.6) of weight, and $39.5 \mathrm{~cm}$ (percentile $<3$ ) of head circumpherence. The patient presented microcephaly, high anterior hairline, broad and prominent frontal region, broad and depressed nasal bridge, bulbous nasal tip, short columella, cupid shaped upper lip, and thick lower lip, microstomia, micrognathia, and short neck (Fig. 1A). A normal-expandable thorax with a systolic murmur, depressible, and non-painful abdomen was detected. At the genital level, he presented penoscrotal hypospadias. Bilateral hypoplasia of the thumbs was evidenced. The patient was neurologically active with adequate muscle tone.

Computerized axial tomography showed lissencephaly. The evaluation by ophthalmology found no refractive errors or alterations in the anterior segment, lens, or fundus. The study of auditory evoked potentials in the brainstem was abnormal on the right side, suggesting sensorineural hearing loss; the study was normal on the left side. The transthoracic echocardiogram showed small ostium secundum interatrial communication without hemodynamic repercussion. Renal ultrasonography revealed a left ectopic kidney, with left renal pyelectasis, and bilateral renal microlithiasis. The X-ray of the hand showed hypoplasia of the thumb (Fig. 1B). The cytogenetic study of the patient showed $46, X Y, r$ (13) in 30 cells analyzed (Fig. 1C). The parents did not present chromosomal alterations.

The clinical evolution of the patient was satisfactory, despite having mild anemia and recurrent respiratory infections that warranted hospitalizations at 14 and 17 months of age. Thyroid profile controls, as well as other biochemical parameters, were within average values.

\section{Discussion}

Three different types of ring chromosome 13 syndrome have been described, according to the location of the cut-off points on the long arm of chromosome 13 during the formation of the ring chromosome. ${ }^{2,8}$ The first group is the most frequent ${ }^{8}$ and involves the loss of segments $13 q 34$ and $13 q 33.2,8$ It is characterized by a cognitive deficit, microcephaly, frontal prominence, hypertelorism, depressed nasal bridge, protruding incisor teeth, large auricular pavilions ${ }^{2}$, and growth retardation ${ }^{6}$. The second group results from the loss of segments $13 q 32$ and $13 q 31^{2,8}$ and is characterized by the findings of the first group, in addition to aplasia of the thumbs and feet, genital anomalies, anal atresia, and ocular malformations. Finally, the third group

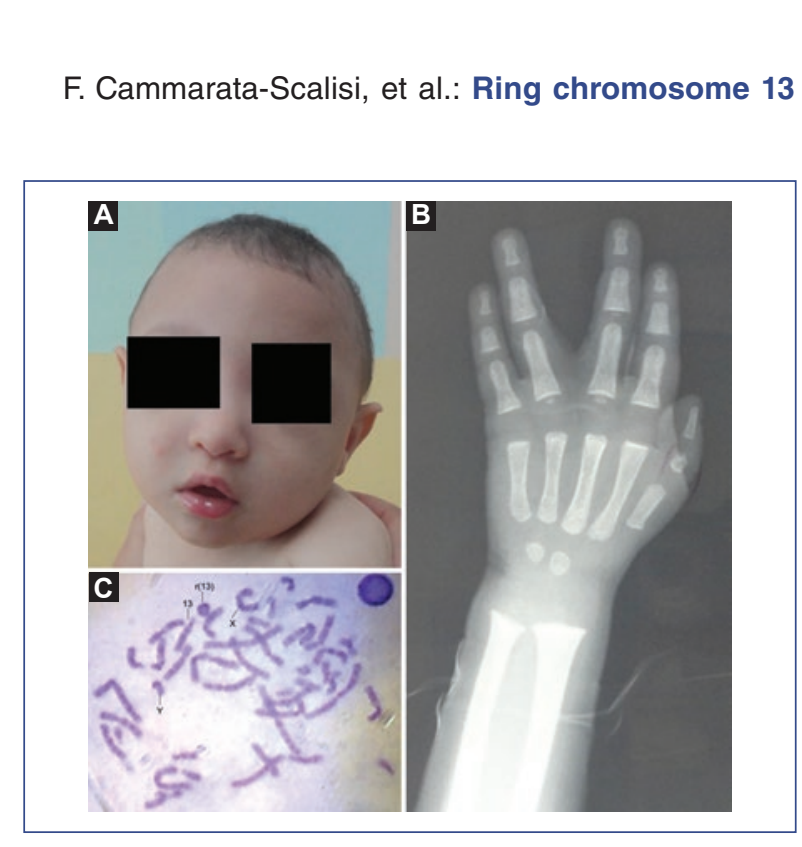

Figure 1. A: Patient with microcephaly, scarce hair. Wwith high anterior implantation, broad frontal region, bulbous nasal tip, and microstomia. B: X-ray of the hand where thumb hypoplasia is observed. C: Cytogenetic study indicates both sex chromosomes (X and $\mathrm{Y}$ ), in addition to the two chromosomes 13 , one of them in ring (r13).

results from the loss of segment 13q21 and presents retinoblastoma as a characteristic finding. ${ }^{2}$

Microarray assays have been useful to define the cut-off points and size of the deletion. ${ }^{3}$ Although this type of analysis was not available, the clinical findings suggest that the patient would belong in the second group due to hypospadias and hypoplasia of the thumbs.

Hypothyroidism has occurred in patients with ging chromosome $13 .{ }^{2}$ This alteration was excluded in the present case with neonatal screening and two subsequent controls. Hearing loss and language delaycare common findings, ${ }^{5}$ which were observed in the patient. Furthermore, in some cases, autism has been described and associated with other neurological disorders, such as cognitive deficit and seizures. ${ }^{1}$ Due to the young age of the patient, some of these findings could not be determined. The medical follow-up is necessary to rule out and treat, as far as possible, the findings that may arise given the varied form of clinical presentation of this condition.

Patients with deletions of the long arm of chromosome 13 may have ambiguous genitalia or hypospadias, which suggests that essential genes for genital development are found in this region. ${ }^{2}$ Moreovero F7 and F10 genes, which code for coagulation factors VII (FVII) and X (FX), respectively, are located in 13â 34 . Therefore, the levels of FVII and FX in patients withring 
chromosome 13 can be found diminished up to $50 \%$ in comparison with an individual without this alteration, for which these patients can present with decreased coagulation times. ${ }^{6}$

Prenatal diagnosis is infrequent. Cases have been reported through amniocentesis studies in patients with a neural tube closure defect. ${ }^{9}$ In the present case, although no prenatal diagnosis was conducted, intrauterine growth retardation can be associated with the presence of a chromosomal disorder.

The clinical characteristics of this condition are varied. Therefore, an interdisciplinary medical evaluation is recommended. This case corresponds to a de novo ring chromosome 13 since the cytogenetic studies performed on the parents were normal. However, the risk of germinal mosaicism, which recurrence is up to $1 \%$, must be considered in both parents. ${ }^{10}$ Consequently, adequate and timely family genetic counseling will be provided. Finally, a thorough prenatal evaluation is recommended to prevent alterations in future pregnancies of the parents.

\section{Ethical considerations}

Protection of human and animal subjects. The authors declare that no experiments were performed on humans or animals for this study.

Confidentiality of data. The authors declare that they have followed the protocols of their work center on the publication of patient data.

Right to privacy and informed consent. The authors have obtained the written informed consent of the patients or subjects mentioned in the article. The corresponding author is in possession of this document.

\section{Conflicts of interest}

The authors declare that they have no conflicts of interest.

\section{Funding}

None.

\section{Acknowledgments}

To Rosalia Gumina, Director of the Library of the Autonomous Institute University Hospital of Los Andes, University of Los Andes.

\section{References}

1. Charalsawadi C, Maisrikhaw W, Praphanphoj V, Wirojanan J, Hanšakunachai $T$, Roongpraiwan $R$, et al. A case with a ring chromosome 73 in a cohort of 203 children with non-syndromic autism and review of the cytogenetic literature. Cytogenet Genome Res. 2014;144:1-8.

2. Ozsu E, Yeșiltepe Mutlu G, Ipekçi B. Ring chromosome 13 and ä̉ ambiguous genitalia. J Clin Res Pediatr Endocrinol. 2014;6:122-4.

3. Kaylor J, Alfaro M, Ishwar A, Sailey C, Sawyer J, Zarate YA. Molecular and cytogenetic evaluation of a patient with ring chromosome 13 and discordant results. Cytogenet Genome Res. 2014:144:104-8.

4. Bedoyan JK, Flore LA, Alkatib A, Ebrahim SA, Bawle EV. Transmission of ring chromosome 13 from a mother to daughter with both having a 46,XX, r(13)(p13q34) karyotype. Am J Med Genet A. 2004;129A:316-20.

5. Abdallah-Bouhjar IB, Mougou-Zerelli $S$, Hannachi H, Gmidène A Labalme A, Soyah N, et al. Molecular cytogenetic and phenotypic characterization of ring chromosome 13 in three unrelated patients. J Pediatr Genet. 2013;2:147-55.

6. Su PH, Chen CP, Su YN, Chen SJ, Lin LL, Chen JY. Smallest" critical region for microcephaly in a patient with mosaic ring chromosome 13 . Genet Mol Res. 2013;12:1311-7.

7. Sankar VH, Phadke SR. Ring chromosome 13 in an infant with guous genitalia. Indian Pediatr. 2006;43:258-60.

8. Brandt CA, Hertz JM, Petersen MB, Vogel F, Noer H, Mikkelsen MDRing chromosome 13: lack of distinct syndromes based on different breakpoints on 13q. J Med Genet. 1992;29:704-8.

9. Chen CP, Tsai CH, Chern SR, Wu PS, Su JW, Lee CC, et al. Prenatal diagnosis and molecular cytogenetic characterization of mosaic ring-chromosome 13. Gene 2013:529:163-8.

10. Firth HV, Hurst JA. Desk reference: clinical genetics. Oxford: Oxford University Press; 2005 